\title{
SYNCHRONIZATION OF CARBOHYDRATE AND PROTEIN SUPPLY IN THE SUGARCANE BAGASSE BASED RATION ON IN SITU NUTRIENT DEGRADABILITY
}

\author{
F. F. Sani, L. K. Nuswantara, E. Pangestu, F. Wahyono and J. Achmadi ${ }^{1}$ \\ Faculty of Animal and Agricultural Sciences, Diponegoro University, \\ Tembalang Campus, Semarang 50275 - Indonesia \\ ${ }^{1}$ Corresponding E-mail:jachmadi@gmail.com
}

Received August 17, 2015; Accepted November 02, 2015

\begin{abstract}
ABSTRAK
Dua ekor domba jantan dewasa digunakan pada dua percobaan untuk mengkaji pengaruh sinkronisasi suplai karbohidrat dan protein dalam pakan komplit berbasis bagase tebu terhadap kecernaan nutrien secara in situ. Percobaan pertama ditujukan untuk menyusun tiga pakan komplit berbasis bagase dengan tiga indeks sinkroni yang berbeda. Semua bahan pakan penyusun dievaluasi untuk mendapatkan gambaran kinetika degradasi bahan organik (BO) dan nitrogen (N) secara in situ. Berdasarkan atas kinetika degradasi $\mathrm{BO}$ dan $\mathrm{N}$, tiga pakan komplit masing-masing diformulasikan dengan indeks sinkroni 0,37 ; 0,50; dan 0,63. Ketiga pakan komplit mengandung protein kasar (PK), energi dan neutral detergent fiber (NDF) yang sama. Percobaan kedua merupakan evaluasi terhadap tiga pakan komplit berbasis bagase tebu dengan indeks sinkroni yang berbeda secara in situ. Degradasi BO pada pakan komplit secara in situ menurun $(\mathrm{P}<0,05)$ dengan peningkatan indeks sinkroni. Semakin meningkat indeks sinkroni semakin meningkatkan $(\mathrm{P}<0,05)$ degradasi PK pada pakan komplit. Perubahan indeks sinkroni pada pakan komplit menurunkan $(\mathrm{P}<0,05)$ degradasi NDF. Semakin meningkat indeks sinkroni pada pakan komplit semakin menurunkan degradasi sulfur, dan ini tidak mendukung tujuan pengaruh sinkronisasi suplai karbohidrat dan protein dalam pakan komplit berbasis bagase.
\end{abstract}

Kata kunci: degradasi nutrien, bagase tebu, sinkronisasi, in situ

\begin{abstract}
Two adult male sheeps fitted with rumen cannula were used in two experiments to study the effects of synchronization of carbohydrate and nitrogen supply in sugarcane bagasse based total mixed ration (TMR) on in situ nutrient degradation. The first experiment was aimed to create three TMR with different synchronization index. Ingredient feedstuffs of TMR were evaluated for its in situ organic matter $(\mathrm{OM})$ and nitrogen $(\mathrm{N})$ degradation kinetics. On the basis of the $\mathrm{OM}$ and $\mathrm{N}$ degradation kinetics of feedstuffs, three sugarcane bagasse based TMR were formulated with synchronization indexes of $0.37 ; 0.50$; and 0.63 ; respectively. The TMR had similar levels of crude protein $(\mathrm{CP})$, total digestible nutrients, and neutral detergent fiber (NDF). In the second experiment, the three TMR with different synchronization index were evaluated for in situ degradability characteristics of OM, CP, NDF, and sulfur. The in situ degradation of $\mathrm{OM}$ in TMR were decreased $(\mathrm{P}<0.05)$ with the increasing of synchronization index. The higher synchronization index in TMR increased $(\mathrm{P}<0.05) \mathrm{CP}$ degradation of CP. The NDF degradation decreased slightly by the alteration of synchronization index in TMR. The higher synchronization index in TMR reduced $(\mathrm{P}<0.05)$ in situ sulfur degradation, and this may not support to effects of synchronization of carbohydrate and nitrogen supply.
\end{abstract}

Key words: in situ, nutrient degradation, sugarcane bagasse, synchronization 


\section{INTRODUCTION}

The synchronization of dietary carbohydrate and protein degradability in rumen is attempted to increase microbial protein synthesis, thus improving the post-ruminal flow of protein. The synchronization of energy and nitrogen supplies in the rumen enhance microbial protein synthesis, improving rumen fermentation efficiency, nurient utilization and animal performance (Seo et al., 2010; Chumpawadee et al., 2006; Sinclair et al., 1993). By contrast, Piao et al. (2012), Rotger et al. (2006) and Chanjula et al. (2004) reported that there is no significant synchronization effect of ruminal nutrient degradability characteristics on rumen fermentation and microbial growth.

Sulfur is one of the most important element for synthesis of sulfur amino acid such as methionine, cystine and cysteine. Methionine is an essential amino acid which has an important role in protein synthesis, as a start codon in the formation of amino acids. Sulfur intake restriction may lower the synthesis of methionine by bacteria, thus microbial protein synthesis may be adjusted to the availability of ruminal sulfur (Karto, 1999). Likewise, dietary sulfur concentration has been found to effect on rumen microbial growth (Suttle, 2010; Pathak, 2008; Stevani and Durand, 1989). The synchronization of supply from ruminal product of carbohydrate and nitrogen degradations is expected to increase microbial protein synthesis. Therefore, ruminal sulfur availability may be an important factor in contributing the improved microbial protein synthesis. The objectives of this study were to evaluate the effects of synchronization of carbohydrate and protein in sugarcane bagasse based total mixed ration on the ruminal degradation of sulfur and other organic nutrients. This was accomplished using the in situ technique.

\section{MATERIALS AND METHODS}

\section{Experiment 1. In situ Degradation Characteristics of Feedstuffs}

This experiment was aimed to determine the characteristics of ruminal nutrient degradation of feedstuffs. Two ruminally cannulated male sheeps with the average body weight of $20 \mathrm{~kg}$ were housed individually in metabolic cages. They were fed on a diet $(12 \% \mathrm{CP} ; 62 \% \mathrm{TDN} ; 55 \%$ NDF) daily at a maintenance level, and drinking water was available ad libitum. After two weeks of adaptation period to the diet and environment, each sheep was subjected to the experiment of in situ degradation characteristics of feedstuffs.

Samples of each feedstuffs were ground through a $2-\mathrm{mm}$ screen and material less than 45 $\mu \mathrm{m}$ was removed by hand sieving. Approximately $5.0 \mathrm{~g}$ of DM of each test feedstuff was accurately weighed into nylon bags with a pore size of 46 $\mu \mathrm{m}$. The bags were then placed into the rumen 30 min after morning feeding and removed after intervals of $0,2,4,6,12,24,48,72 \mathrm{~h}$. For each incubation time, each sample of feedstuff was tested in triplicates in each sheep, randomly. Following incubation, the bags and contents were washed using aquademineral through the cold rinse cycle of a washing machine. Zero-hour bags were not incubated in the rumen but were washed in the same manner as incubated bags. After washing, bags and contents were dried in an oven at $60^{\circ} \mathrm{C}$ for $48 \mathrm{~h}$ and reweighed. Residue in the bags from the incubation period were analyzed to know the percentage of disappearance organic matter (OM) and crude protein (CP). The degradability data obtained for $\mathrm{N}$ and $\mathrm{OM}$ for feedstuffs were fitted to the model of Ǿrskov dan McDonald (1979) $\mathrm{p}=\mathrm{a}+\mathrm{b}\left(1-\exp { }^{(-\mathrm{ct})}\right)$, where $p$ is the cumulative amount degraded at time $t, a$ is the rapidly soluble fraction, $b$ is the potentially degraded fraction and $c$ is the rate of degradation of fraction $b$.

The synchronization index of each feedstuff was calculated based on degradation values of $\mathrm{N}$ to OM as described by Sinclair et al. (1993):

Synchronization Index $=\frac{25-\left[1-24 \sqrt{\frac{\left(25-\frac{\mathrm{N}}{\mathrm{OM}} \mathrm{kg}\right)^{2}}{24}}\right.}{25}$

where 25 is $25 \mathrm{~g}$ of N/kg of digested OM in the rumen (Czerkawski, 1986), a synchronization index of 1.0 represent perfect synchronization between $\mathrm{N}$ and $\mathrm{OM}$ supply throughout the day and values less than 1.0 indicate the degree of ansynchronization.

Three formulas of experimental diets were created on the basis of synchronization index value of each ingredient. The experimental diets were formulated to have synchronization indexes of $0.37 ; 0.50$; and 0.63 ; respectively. The diets were in the form of total mixed ration (TMR) and were designed to have similar CP, TDN and NDF levels. Urea and molasses were used in formulating the diets. This was assumed that $95 \%$ of urea $\mathrm{N}$ was degraded in the first hour after 
feeding, with the remaining $5 \%$ of urea $\mathrm{N}$ degraded at a rate of $0.5 / \mathrm{h}$ (Sinclair et al., 1995). Molasses was assumed at $100 \%$ of $\mathrm{N}$ and OM was degraded in the first hour post feeding (Chumpawadee et al., 2006).

\section{Experiment 2. Evaluation of Bagasse Based TMR with Different Synchronization Index}

The Experiment 2 was aimed to study the effect of the synchronization index alteration in sugarcane bagasse based TMR on the in situ degradation of sulfur, OM, CP and NDF. Three formulas of sugarcane bagasse based TMR resulted from Experiment 1 were used in this evaluation (Table 2). Animal, environment, and procedures of the in situ technique were similar to the Experiment 1. During the in situ technique, sheep were fed on TMR according to the test of TMR. Animals were fed TMR daily at maintenance level in two equal meals at $06.00 \mathrm{~h}$ and $18.00 \mathrm{~h}$. Drinking water was available at all times throughout experimental period.

Feed and residue in nylon bags were analyzed for sulfur, OM, CP, and NDF. Sulfur, $\mathrm{OM}$, and CP contents of feed and residue were analyzed according to the procedure of AOAC
(2000). A crossover design (two animals; three synchronization index treatments) was used to allocate the treatment of synchronization index alteration with six replicates of each treatment, and one way analyse of variance was used to test the data.

\section{RESULTS}

\section{Experiment 1}

Nutrient composition and synchronization index of each feedstuff ingredient are presented in Table 1. The feedstuff ingredients varied widely in their chemical compositions. The CP content of cassava waste was the lowest, and the CP content of soybean mill was the highest. The NDF and ADF contents of soybean $m$ was the lowest, and the NDF and ADF contents of sugarcane bagasse was the highest. The ash content of rice bran was the highest and the ash content of maize grain was the lowest.

The synchronization index was calculated on the basis of $\mathrm{N}$ and $\mathrm{OM}$ ruminal degradation characteristics for each feedstuff ingredients. The feedstuff ingredients had variation in their synchronization indexes. The synchronization

Table 1. Chemical Compositions of Feedstuffs for TMR Formulation

\begin{tabular}{|c|c|c|c|c|c|c|c|c|}
\hline \multirow{2}{*}{ Feedstuffs } & $\mathrm{OM}$ & TDN & $\mathrm{CP}$ & Ash & NDF & $\mathrm{ADF}$ & Sulfur & \multirow[t]{2}{*}{ SI } \\
\hline & \multicolumn{7}{|c|}{ 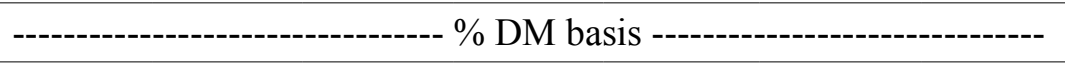 } & \\
\hline Sugarcane bagasse & 96.66 & 49.49 & 1.75 & 3.34 & 89.07 & 53.98 & 0.63 & 0.088 \\
\hline Rice bran & 87.20 & 66.64 & 6.01 & 12.80 & 61.21 & 28.39 & 0.10 & 0.668 \\
\hline Molasses & 92.91 & 80.64 & 1.15 & 7.09 & - & - & 0.84 & 1.000 \\
\hline Copra mill & 93.32 & 55.21 & 14.98 & 6.68 & 62.35 & 35.51 & 0.25 & 0.847 \\
\hline Urea & - & - & 287.5 & - & - & - & - & 0.950 \\
\hline Palm frond mill & 96.94 & 61.78 & 15.07 & 3.06 & 75.19 & 45.33 & 0.06 & 0.627 \\
\hline Coffe seed shell & 90.13 & 47.68 & 7.37 & 9.87 & 72.58 & 51.69 & 0.15 & 0.558 \\
\hline Cassava waste & 95.55 & 64.99 & 1.49 & 4.45 & 35.28 & 21.76 & 0.03 & 0.112 \\
\hline Wheat pollard & 95.14 & 75.74 & 12.83 & 4.86 & 51.10 & 20.69 & 0.05 & 0.891 \\
\hline Groundnuts shell & 91.47 & 34.38 & 5.59 & 8.53 & 69.68 & 56.89 & 0.12 & 0.286 \\
\hline Corn & 98.79 & 80.06 & 8.84 & 1.21 & 51.07 & 17.56 & 0.16 & 0.528 \\
\hline Soybean mill & 93.34 & 82.23 & 47.96 & 6.66 & 11.66 & 8.87 & 0.45 & 0.960 \\
\hline Salt & - & - & - & - & - & - & - & - \\
\hline
\end{tabular}

$\mathrm{OM}=$ Organic matter, $\mathrm{TDN}=$ Total digestible nutrients, $\mathrm{CP}=$ Crude protein, $\mathrm{NDF}=$ Neutral detergent fiber, $\mathrm{ADF}=$ Acid detergent fiber, $\mathrm{SI}=$ Synchronization Index 
index of soybean mill was the highest and the synchronization index of sugarcane bagasse was the lowest. Table 2 shows the experimental TMR which were formulated with synchronization indexes of 0.37 ; 0.50 ; and 0.63 ; respectively. These diets had similar contents of CP, TDN, and NDF.

\section{Experiment 2}

Figure 1 shows the percentage loss of OM, $\mathrm{CP}, \mathrm{NDF}$, and sulfur of three TMR with respective synchronization indexes throughout the incubation times. There were rapid increases in nutrient disappearances during the first $24 \mathrm{~h}$ of incubation time, then the rates of nutrient disappearances were plateau throughout the second $24 \mathrm{~h}$ of incubation time. Table 3 shows the in situ nutrient degradation characteristics of TMR with different synchronization index, those were calculated on the basis of data from Figure 1.

The higher synchronization index of TMR lowered $(\mathrm{P}<0.05)$ fraction $\mathrm{a}+\mathrm{b}$ of $\mathrm{OM}($ Table 3$)$. In contrast, higher synchronization index of TMR

Table 2. Ingredients and Chemical Composition of TMR with Different Synchronization Index

\begin{tabular}{|c|c|c|c|}
\hline & \multicolumn{3}{|c|}{ Synchronization Index } \\
\hline & 0.37 & 0.50 & 0.63 \\
\hline \multicolumn{4}{|l|}{ Ingredient } \\
\hline Sugarcane bagasse & 25.00 & 25.00 & 25.00 \\
\hline Rice bran & 2.50 & 4.00 & 5.60 \\
\hline Molasses & 2.00 & 4.00 & 7.00 \\
\hline Copra mill & 2.50 & 6.00 & 16.30 \\
\hline Urea & 0.70 & 0.50 & 0.20 \\
\hline Palm frond mill & 16.50 & 9.00 & 1.00 \\
\hline Coffe seed shell & 2.30 & 2.00 & 3.80 \\
\hline Cassava waste & 30.20 & 15.50 & 2.20 \\
\hline Wheat pollard & 1.10 & 15.50 & 23.00 \\
\hline Groundnuts shell & 1.60 & 3.50 & 3.60 \\
\hline Corn & 5.80 & 4.50 & 0.50 \\
\hline Soybean mill & 11.30 & 10.00 & 11.30 \\
\hline Salt & 0.50 & 0.50 & 0.50 \\
\hline Total & 100.00 & 100.00 & 100.00 \\
\hline \multicolumn{4}{|c|}{ Analyzed chemical composition (\%) } \\
\hline Organic matter & 95.64 & 95.03 & 94.13 \\
\hline Crude protein & 12.06 & 12.17 & 12.95 \\
\hline Total digestible nutrients 1 & 62.05 & 62.93 & 62.96 \\
\hline Neutral detergent fiber & 54.80 & 55.97 & 55.98 \\
\hline Acid detergent fiber & 32.85 & 32.12 & 31.67 \\
\hline Cell contents & 45.20 & 44.03 & 44.02 \\
\hline Hemicellulose & 21.95 & 23.85 & 24.31 \\
\hline Sulfur contents & 0.26 & 0.29 & 0.34 \\
\hline $\mathrm{N}: \mathrm{S}$ ratio & $7.4: 1$ & $6.7: 1$ & $6.1: 1$ \\
\hline
\end{tabular}

${ }^{1}$ Calculated according to Harris et al. (1972) 
Table 3. In situ Degradability of Bagasse Based TMR with Different Synchronization Index

\begin{tabular}{lccc}
\hline & \multicolumn{3}{c}{ Synchronization Index } \\
\cline { 2 - 4 } Parameters & 0.37 & 0.50 & 0.63 \\
\hline OM degradability & $34.88 \pm 0.60^{\mathrm{a}}$ & $28.21 \pm 0.78^{\mathrm{c}}$ & $31.11 \pm 0.70^{\mathrm{b}}$ \\
a (\%) & $23.32 \pm 0.73^{\mathrm{c}}$ & $29.12 \pm 1.18^{\mathrm{a}}$ & $25.09 \pm 1.14^{\mathrm{b}}$ \\
$\mathrm{b}(\%)$ & $5.97 \pm 0.46^{\mathrm{a}}$ & $5.44 \pm 0.30^{\mathrm{b}}$ & $4.14 \pm 0.32^{\mathrm{c}}$ \\
c (\% / h) & $58.12 \pm 0.27^{\mathrm{a}}$ & $57.33 \pm 0.49^{\mathrm{b}}$ & $56.12 \pm 0.71^{\mathrm{c}}$ \\
$\mathrm{a}+\mathrm{b}(\%)$ & & & \\
CP degradability & $38.82 \pm 0.84^{\mathrm{a}}$ & $21.52 \pm 0.94^{\mathrm{b}}$ & $17.65 \pm 1.80^{\mathrm{c}}$ \\
a (\%) & $25.08 \pm 0.96^{\mathrm{c}}$ & $47.11 \pm 1.14^{\mathrm{b}}$ & $52.59 \pm 2.21^{\mathrm{a}}$ \\
b (\%) & $6.82 \pm 0.50^{\mathrm{a}}$ & $6.28 \pm 0.21^{\mathrm{b}}$ & $6.98 \pm 0.42^{\mathrm{a}}$ \\
c (\% / h) & $63.90 \pm 0.23^{\mathrm{c}}$ & $68.63 \pm 0.36^{\mathrm{b}}$ & $70.34 \pm 0.48^{\mathrm{a}}$ \\
a+b (\%) & & & \\
NDF degradability & $10.45 \pm 0.94$ & $8.51 \pm 1.40$ & $9.66 \pm 1.40$ \\
a (\%) & $20.25 \pm 1.04$ & $19.35 \pm 2.05$ & $20.21 \pm 2.30$ \\
b (\%) & $5.66 \pm 0.72$ & $5.78 \pm 0.98$ & $5.25 \pm 1.03$ \\
c (\% / h ) & $30.71 \pm 0.45^{\mathrm{a}}$ & $27.86 \pm 0.85^{\mathrm{b}}$ & $29.89 \pm 1.41^{\mathrm{ab}}$ \\
a+b (\%) & & & \\
Sulfur degradability & $1.48 \pm 0.29^{\mathrm{b}}$ & $0.98 \pm 0.26^{\mathrm{b}}$ & $4.15 \pm 1.30^{\mathrm{a}}$ \\
a (\%) & $78.40 \pm 0.14^{\mathrm{a}}$ & $63.84 \pm 0.42^{\mathrm{b}}$ & $48.73 \pm 0.83^{\mathrm{c}}$ \\
b (\%) & & & \\
c (\% / h) & $53.47 \pm 2.44^{\mathrm{a}}$ & $40.99 \pm 0.61^{\mathrm{b}}$ & $27.09 \pm 1.19^{\mathrm{c}}$ \\
a+b (\%) & $24.93 \pm 2.54^{\mathrm{a}}$ & $22.85 \pm 0.23^{\mathrm{b}}$ & $21.64 \pm 0.87^{\mathrm{c}}$ \\
\hline
\end{tabular}

Values are means $\pm \operatorname{SE}(\mathrm{n}=6)$

$\mathrm{a}, \mathrm{b}, \mathrm{c} \mathrm{P}<0.05$

increased $(\mathrm{P}<0.05)$ the degradable fraction $\mathrm{a}+\mathrm{b}$ of CP. The fraction $a+b$ degradability of NDF decreased slightly with the increasing value of synchronization index of TMR. The higher synchronization index of TMR lowered $(\mathrm{P}<0.05)$ the fraction $\mathrm{a}+\mathrm{b}$ of sulfur.

\section{DISCUSSIONS}

\section{Sugarcane Bagasse Based TMR with Different Synchronization Index}

The sugarcane based TMR could be an alternative to secure feed availability for ruminants throughout the year, though the existence of most fiber components in sugarcane bagasse are tightly bound to lignin as lignohemicelluloses and lignocelluloses. This study evaluated the in situ sulfur and other nutrient degradability of sugarcane bagasse based TMR with different synchronization index. The TMR were created using similar ingredient of feedstuffs, but the ruminal supply of energy and nitrogen of all ingredients were synchronized to favor the improvement of microbial protein synthesis. The levels of CP, TDN, NDF, and sulfur were similar among the TMR to avoid any effect of different chemical composition in the tested TMR (Table 2). The levels of CP and TDN in TMR were designed as the recommendation of Kearl (1982). Moreover, sugarcane bagasse portions were also similar in the TMR, because sugarcane bagasse had the lowest $\mathrm{CP}$ and 

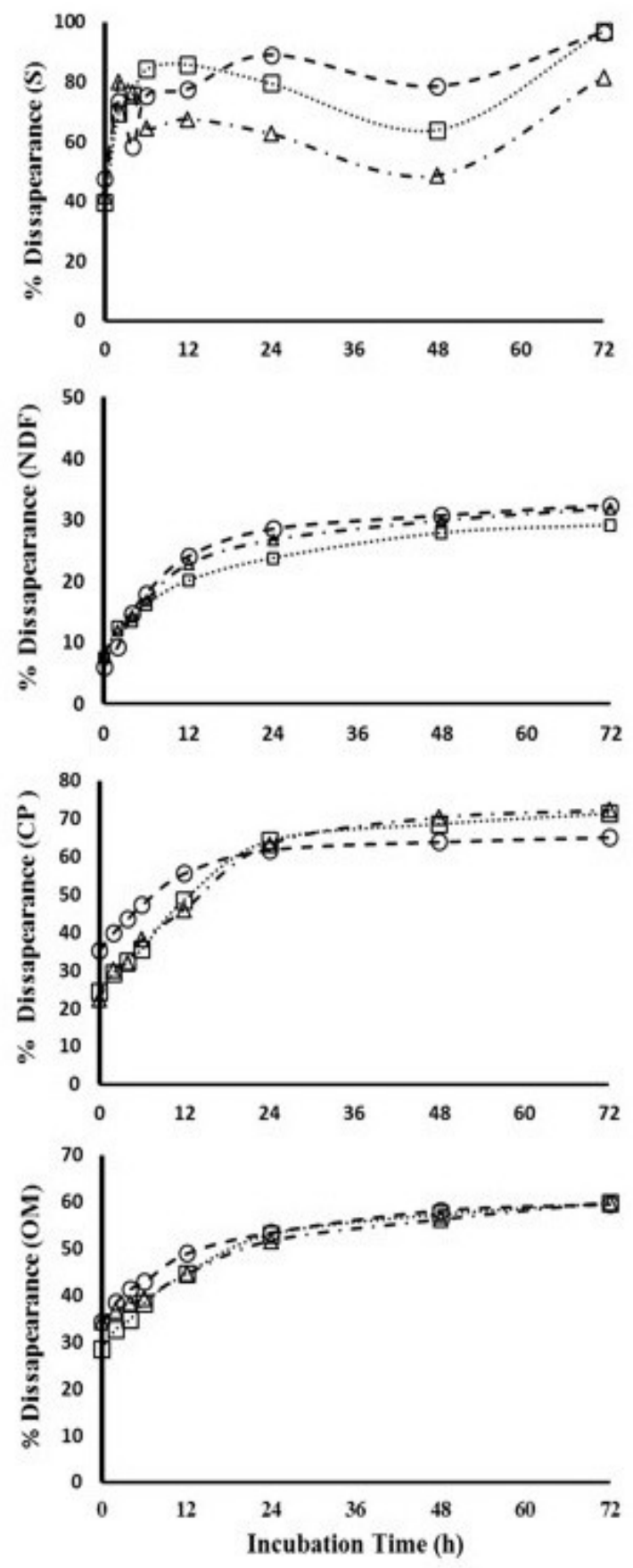

Figure 1. Dissapearance of sulfur (S), neutral detergent fiber (NDF), crude protein (CP) and organic matter $(\mathrm{OM})$ with synchrony indexes of $0.37(O), 0.50(\square)$ and $0.63(\triangle)$, respectivelly.

synchronization index and the highest NDF compared to other ingredients (Table 1). The ratios of $\mathrm{N}$ to sulfur in the TMR were relatively low to contribute an optimum rumen microbial growth. Suwandyastuti (2013) reported that the ratio of $\mathrm{N}$ to sulfur at 9.09 may maximize the in vitro growth of rumen microbes. The ratio of $\mathrm{N}$ to sulfur at 10 in diet results maximum nitrogen retention in Naeimi sheep (Al-Dobeeb, 2004).

\section{In situ Organic Nutrient Degradability of TMR}

Generally, ruminant diet is characterized with relatively more rapid ruminal degradation of dietary nitrogen than those of dietary carbohydrate. The synchronization of protein and carbohydrate supply means providing both rumen degradable protein (rumen degradable protein; non protein $\mathrm{N}$ and rumen degradable true protein) and energy (ruminally fermentable carbohydrates) to the rumen, so that ruminal microorganisms use both simultaneously (Yang et al., 2010; Hall and Huntington, 2008). The synchronization of the ruminal degradation rate of carbohydrates and protein has been proposed as a method to increase ruminal microbial protein synthesis, improve efficiency of $\mathrm{N}$ usage and animal performance, and decrease urinary $\mathrm{N}$ excretion.

Using the in situ method, Orskov and McDonald (1979) explain the nutrient degradation characteristic of tested feed on the basis of the rapidly soluble fraction of nutrients, the potentially degradable fraction of nutrient, and degradation rate of the potentially degradable fraction of nutrient, respectively which were delineated as values of a, b, and c. Kim et al. (2014) suggested that the DM of tested feeds are classified into water-soluble and $45-\mathrm{mm}$ filterable, insoluble degradable, and non-degradable fraction. The digestible NDF would be completely degraded in the rumen within $72 \mathrm{~h}$. The portion of NDF that remained after $72 \mathrm{~h}$ of incubation was considered the indigestible fraction. The $\mathrm{CP}$ of tested feeds are classified into water-soluble and 45-mm filterable, insoluble degradable, and nondegradable fractions. The portion of $\mathrm{CP}$ that remained after $48 \mathrm{~h}$ of incubation was considered the non-degradable fraction.

The higher synchronization index in TMR may prevent acids accumulation that cause an abrupt reduce in ruminal $\mathrm{pH}$. Kim et al. (2014) concluded that higher portion of soluble carbohydrates in a diet increases ruminal concentration of lactic acid concomitantly with reduces ruminal $\mathrm{pH}$. The decrease in ruminal $\mathrm{pH}$ do not favor to the growth of rumen microbes. Table 3 shows that the rapidly degradable OM fraction decreased $(\mathrm{P}<0.05)$ and the potentially degradable portion of $\mathrm{OM}$ fraction increased $(\mathrm{P}<0.05)$ by increasing the synchronization index. 
Although the impact of synchronization index alteration in the lower digestive tract may have diluted the influence on rumen fermentation, there were some inconsistency results of in vivo studies. The in vivo OM digestibility are unchanged with the increasing synchronization index in the diets (Piao et al., 2012; Rotger et al., 2006; Chanjula et al., 2004). In contrast, the higher synchronization index of diets slightly increases in vivo $\mathrm{OM}$ digestibility of diets (Seo et al., 2010; Chumpawadee et al., 2006).

Table 3 shows that the higher synchronization index decreased $(\mathrm{P}<0.05)$ the rapid degradable fractions of dietary $\mathrm{CP}$ and increased $(\mathrm{P}<0.05)$ the potentially degradable fractions of dietary CP. These results were in line with degradability characteristics of $\mathrm{OM}$ fraction. Therefore, the synchronization of ruminal dietary $\mathrm{OM}$ and $\mathrm{CP}$ releases could be used simultaneously for the growth of rumen microbes (Yang et al., 2010; Hall and Huntington, 2008). Moreover, the higher synchronization index increased $(\mathrm{P}<0.05)$ the sum of the rapid degradable and the potentially degradable fractions of dietary $\mathrm{CP}$ (Table 3). Although the impact of synchronization index alteration in the lower digestive tract may have diluted the influence on rumen fermentation, the in vivo $\mathrm{CP}$ digestibility increased according to the increasing of synchronization index in diets (Chumpawadee et al., 2006).

The sum of rapid degradable and potentially degradable dietary NDF decreased $(\mathrm{P}<0.05)$ by the alteration of synchronization index, but both fractions were unaffected by the alteration of synchronization index in the TMR (Table 3). The discrepancy between degradation characteristic of dietary NDF with other organic nutrients may be caused by the degradability dietary lignin, although the in situ degradation characteristic of lignin was not determined in this study. Dietary NDF consists of hemicellulose, cellulose, lignin and other nutrients bound to lignin. The portion of sugarcane bagasse in TMR was the highest among ingredient feedstuffs (Table 2). Most fiber components of sugarcane bagasse are tightly bound to lignin as lignohemicelluloses and lignocelluloses (Ariyani et al., 2014; Ramli et al., 2005).

\section{In situ Sulfur Degradability of TMR}

The synchronization of ruminal carbohydrate and nitrogen supply may create an environment that favor optimum microbial synthesis. Optimum microbial protein synthesis and sulfur capture occur when fermentable energy, degradable sulfur, nitrogen and phosphorus are supplied at rates that match the capacity of optimum microbial protein synthesis (Suttle, 2010). When a large amount of urea to substitute natural protein in a ruminant diet, limited sulfur intake and may restrict microbial protein synthesis (Pathak, 2008). The sulfur capture for synthesis of microbial methionine and cystine requires more degradable source of feed carbohydrate (Stevani and Durand, 1989). However, it is not clear why all in situ degradation characteristics of sulfur decreased $(\mathrm{P}<0.05)$ with increasing the synchronization index in TMR (Table 3 ).

The reduced ruminal NDF degradation may attribute to the decreased sulfur degradation. Rumen microbes are well known to have the capability in degrading lignocellulolitic bonds, therefore rumen is the most important site for mineral availability to animal host and rumen microbes. Some parts of feed mineral are associated with the cell wall in cellulolitic diet, and ruminal release of mineral depends on degradability of feed NDF (Ceresnakova et al., 2007; Ibrahim and Zemmelink, 1999).

\section{CONCLUSION}

The synchronization of carbohydrate and nitrogen supply in TMR reduced ruminal OM digestibility and increased $\mathrm{CP}$ digestibility. It is suggested that the decreased ruminal $\mathrm{OM}$ degradation may match with rate of $\mathrm{CP}$ degradation. However, degradability of NDF and sulfur did not favor to microbial protein synthesis. Future study needs to consider some aspects concerning with micro flora fauna environment of rumen.

\section{REFERENCES}

Al-Dobeeb, S.N. 2004. Evaluation of digestibility, nitrogen and sulfur balances and rumen fermentation of diets supplemented with urea and/or potassium sulfate in Naeimi sheep. Pak. J. Biol. Sci. 7(12):2216-2221.

AOAC. 2000. Official methods of analysis, $17^{\text {th }}$ Ed. Association of Official Analytical Chemists. Washington DC.

Ariyani, S. A., L.K. Nuswantara, E. Pangestu, F. Wahyono and J. Achmadi. 2014. Parameters of potein metabolism in goats fed diets with different portion of sugarcane bagasse. J. Indonesia Trop. Anim. Agric. 39(2): 111- 
116.

Ceresnakova, Z., P. Flak, M. Polacikova and M. Chrenkova. 2007. In sacco macromineral release from selected foreges. Czech. J. Anim. Sci. 52(6):175-182.

Chanjula, P., M. Wanapat, C. Wachirapaorn and P. Rowlinson. 2004. Effects of synchronizing starch sources and protein (NPN) in the rumen on feed intake, rumen microbial fermentation, nutrient utilization and performance of lactating dairy cows. AsianAust. J. Anim. Sci. 17:1400-1410.

Chumpawadee, S., K. Sommart, T. Vongpralub and V. Pattarajinda. 2006. Effect of synchronizing the rate of dietary energy and nitrogen release on ruminal fermentation, microbal protein synthesis, blood urea nitrogen and nutrient digestibility in beef cattle. Asian-Aust. J. Anim. Sci. 19(2):181188.

Czerkawski， J. W. 1986. An Introduction to Ruminal Studies. Oxford: Pergamon Press (Ed. H. J. Finalyson) 1986. The effect of $\mathrm{pH}$ on the growth and metabolism of Streptococcus bovis in continous culture. J. Appl. Bacteriol. 61:201-208.

Hall, M. B. and G. B. Huntington. 2008. Nutrient synchrony: Sound in theory, elusive in practice. J. Anim. Sci. 86(E.Suppl.): E287E292.

Harris, L. E., L. C. Kearl and P. V. Fonnesbeck. 1972. Use of regression equations in predicting availability of energy and protein. J. Animal Sci. 35 (3):658-680.

Ibrahim, M. N. M. and G. Zemmelink. 1999. Effect of plant fibre on the solubility of mineral elements. Asian-Aust. J. Anim. Sci. 12(8):1277-1284.

Karto, A. A. 1999. Peran dan kebutuhan sulfur pada ternak ruminansia. Wartazoa 8(2):3843.

Kearl, L. C. 1982. Nutrient Requirements of Ruminants in Developing Countries. International Feed Stuffs Institute. Utah Agriculture Experimental Station. Utah State University, Logon, Utah, USA. pp. 45-58.

Kim, Y.I., Y.K. Oh. K.K. Park, and W.S. Kwak. 2014. Ensiling characteristics and the in situ degradability of a by-product feed based silage. Asian-Aust. J. Anim. Sci. 27(2):201208.

Ǿrskov, E. R. and I. McDonald. 1979. The estimation of protein degradability in the rumen from incubation measurements weight according to rate of passage. J. Agric. Sci., Cambridge. 92:499-503.

Pathak, A. K. 2008. Various factors affecting microbial protein synthesis in rumen. Veterinary World. 1(6):186-189.

Piao, M.Y., H.J. Kim, J.K. Seo, T.S. Park, J.S. Yoon, K.H. Kim, and J.K. Ha. 2012. Effects os synchronization of carbohydrate and protein supply in total mixed ration with Korean wine residue on ruminal fermentation, nitrogen metabolism and microbial protein synthesis in Holstein steers. Asian-Aust. J. Anim. Sci. 25(11):1568-1574.

Ramli, M.N., Y. Imura, K. Takayama, and Y. Nakanishi. 2005. Bioconversion of sugarcane bagasse with Japanese koji by solid-state fermentation and its effects on nutritive value and preference in goats. Asian-Aust. J. Anim. Sci. 18(9):1279-1284.

Rotger, A., A. Ferret, S. Calsamiglia and X. Manteca. 2006. Effects of nonstructural carbohydrate and protein sources on intake, apparent total tract digestibility, and ruminal metabolism in vivo and in vitro with highconcentrate beef cattle diets. J. Anim. Sci. 84:1188-1196.

Seo, J. K., J. Yang, H. J. Kim, S. D. Upadhaya, W. M. Cho and J. K. Ha. 2010. Effects of synchronization of carbohydrate and protein supply on ruminal fermentation, nitrogen metabolism and microbial protein synthesis in holstein steers. Asian-Aust. J. Anim. Sci. 23(11):1455-1461.

Sinclair, L. A., P. C. Garnsworthy, J. R. Newbold and P. J. Buttery. 1993. Effects of synchronizing the rate dietary energy and nitrogen release on rumen fermentation and microbal protein synthesis in sheep. J. Agric. Sci. 120:251-263.

Sinclair, L. A., P. C. Garnsworthy, J. R. Newbold and P. J. Buttery. 1995. Effects of synchronizing the rate dietary energy and nitrogen release in diets with a similiar carbohydrate composition on rumen fermentation and microbial protein synthesis in sheep. J. Agric. Sci. 124:463-472.

Stevani, J. and M. Durand. 1989. Effect of sulphur deficiency on fermentation of different carbohydrate sources in an artificial rumen (RUSITEC). Asian-Aust. J. Anim. Sci. 2(3):399-389.

Suttle, N. F. 2010. Mineral Nutrition of Livestock. $4^{\text {th }}$ Ed. CAB International, Cambridge. Pp. 
206-222.

Suwandyastuti, S. N. O. 2013. Pengaruh nisbah energi-protein, nitrogen-sulfur dan kalsiumfosfor terhadap produk metabolisme rumen dan kecernaan substrat. Agripet. 13(2): 1-6.
Yang, J. Y., J. Seo, H. J. Kim, S. Seo and J. K. Ha. 2010. Nutrient synchrony: Is it a suitable strategy to improve nitrogen utilization and animal performace?. Asian-Aust. J. Anim. Sci. 23: 972-979 